\title{
ALGATIKA: MATHEMATICS PRIVATE LENDING APPLICATIONS AS AN EFFORT TO INCREASE STUDENTS LEARNING INTEREST IN MATHEMATICS LEARNING
}

\author{
$\underline{\text { Septi Rahmita Sari1 }}^{*}$, Amelia T. R. Sidik ${ }^{1}$, Farhah Nadhilah ${ }^{1}$, Nisky Imansyah Yahya ${ }^{1}$ \\ ${ }^{1}$ Department of Mathematics, Universitas Negeri Gorontalo \\ Jl. Prof. Dr. Ing. BJ Habibie, Moutong, Tilongkabila, Bone Bolango Regency, Gorontalo Province \\ 96119, phone/fax: (0435) 821125 \\ *email: septirahmita1234@gmail.com
}

\begin{abstract}
Abstrak: Di era pembangunan berkelanjutan sekarang ini, pendidikan merupakan hak mendasar bagi setiap orang. Pendidikan pada dasarnya adalah suatu proses membantu manusia dalam mengembangkan dirinya sehingga mampu menghadapi segala permasalahan dengan sikap terbuka. Salah satu cara untuk membantu para siswa memperjelas konsep dan pemahaman matematika yang sedang dipelajari pada saat pembelajaran berlangsung adalah dengan menggunakan alat peraga. Alat peraga berfungsi untuk memperlancar tujuan dari pelaksanaan pembelajaran di sekolah. Tetapi kenyataannya penggunaan alat peraga matematika pada saat pembelajaran di sekolah belum membudaya, pada khususnya di daerah yang jauh dari perkotaan masih banyak yang belum mempunyai alat peraga. Hal ini secara langsung berdampak terhadap kurangnya pemahaman dan pengalaman belajar siswa sehingga mengakibatkan hasil belajar siswa menjadi rendah. Karya tulis ini akan memperkenalkan dan membahas tentang ALGATIKA sebuah aplikasi peminjaman alat peraga matematika untuk SD dan SMP yang nantinya dapat dimanfaatkan untuk pemecahan masalah tersebut. Metodologi penelitian yang digunakan adalah metode deskriptif kualitatif dengan pendalaman materi melalui studi literatur. Hasilnya diketahui bahwa permasalahan kurangnya alat peraga di beberapa sekolah sebenarnya dapat diatasi oleh ALGATIKA aplikasi peminjaman alat peraga matematika di SD dan SMP. Dengan demikian aplikasi ini dapat membantu menyediakan alat peraga yang dibutuhkan dimana hal tersebut dapat membangun dan meningkatkan fasilitas pendidikan serta menyediakan lingkungan belajar yang efektif bagi semua. Hal ini juga dapat mengembangkan proses belajar-mengajar siswa sehingga dapat menciptakan pendidikan yang lebih berkualitas yang mengarah pada capaian pembelajaran yang relevan dan efektif sesuai dengan target dari SDG's di bidang pendidikan.
\end{abstract}

Kata Kunci : alat peraga, algatika, pembelajaran matematika.

\begin{abstract}
In the era of sustainable development, education is a fundamental right for everyone. Education is a process of helping humans develop themselves so that they can face all problems with an open attitude. One way to help students clarify the concepts and understanding of mathematics that is being studied during the learning process is by using teaching aids. Teaching aids serve to facilitate the purpose of implementing learning in schools. However, the fact is that the use of mathematics teaching aids during learning at school is not yet entrenched, especially in areas far from urban areas, many of which do not have teaching aids. This directly impacts students' lack of understanding and learning experience, resulting in low student learning outcomes. This paper will introduce ALGATIKA, an application of lending mathematics teaching aids for elementary and junior high schools which can later solve these problems. The research methodology used is a qualitative descriptive method by deepening the material through literature studies. The result is that the lack of teaching aids in some schools can be overcome by the ALGATIKA application of lending mathematics teaching aids in elementary and junior high schools. Thus this application can help provide the teaching aids needed to build and improve educational facilities and provide an effective learning environment for all. It can develop students' teaching and learning processes and create higher quality education which leads to relevant and effective learning outcomes in accordance with the targets of the SDG's in education.
\end{abstract}

Keywords : props, algatika, mathematics learning. 


\section{INTRODUCTION}

Based on KBBI, education is the process of changing attitudes or the process of self-development and behavior of a person or group of people to mature humans through teaching and training efforts so that they can face all problems with an open attitude. As stated in the goals of national education which have been formulated that: National education aims to educate the nation's life and develop Indonesian people as a whole. An educational institution must realize that a student's success in learning at school can be seen from the availability of complete educational facilities to support the teaching and learning process. Based on Government Regulation No: 19 of 2005 in chapter VII article 42, paragraph 1 states that: every educational unit is required to have facilities which include furniture, educational equipment, educational media, learning resources or other references apart from books, disposable equipment, and other equipment needed to support regular and sustainable teaching and learning activities. In order for this success to be achieved in the learning process, it requires media or props that can improve the process and learning outcomes in accordance with the level of thinking of students.

In international journals, the results of analysis and research, several things are formulated that show the difficulties of elementary school students in solving problems related to mathematics based on student survey tests 1) students do not like very long explanations related to questions, 2) students do not understand the problems that exist. In the questions, and the average student will only guess without thinking about where it came from, 3) students' impatience and dislike of reading, 4) unable to express opinions optimally, and 5) students are still confused about how to change the story problem to become a symbol. (Prathana Phonapichat, 2013)

According to Nasution (2003: 100), teaching aids support teaching tools to be more effective. The visual aid serves to demonstrate a subject in the teaching and learning process. One of them is in the mathematics learning process. The teaching aid itself has an important meaning in learning mathematics because it is related to abstraction or requires other media. In the elementary school mathematics learning guidelines issued by the Ministry of National Education (2010), it is stated that in elementary school mathematics learning, using concrete objects as teaching aids is indispensable in naming concepts so that students understand mathematical concepts/principles more easily and quickly.

Quoted from the journal Development of teaching aids in improving mathematics learning abilities in children with ADHD: Limitations of teaching aids, especially Mathematics in schools, are a major obstacle for teachers in conveying and imparting a Mathematical concept. Quoted from the Siliwangi dedication journal, volume 4, number 2, 2018, the number of teaching aids, especially mathematics teaching aids, is currently very minimal in schools because government assistance in the form of procurement of mathematics teaching aids is very rare. Aid to schools is currently in liquid funds known as School Operational Assistance (BOS) which can be used to buy teaching aids in certain shops that provide various learning media. However, the problem faced by schools in remote areas is the absence of a complete shop that provides various mathematics teaching aids. On the other hand, 
campuses or even some well-known schools have extra teaching aids that are rarely used and sometimes no longer used because of new teaching aids.

The availability of teaching aids is one of the most important things to help the learning process so that the results obtained are maximized. If things like this are allowed to continue, it will decrease students' quality because the learning process they follow does not develop their level of understanding. Therefore, every school should have teaching aids that can be used. We can use increasingly sophisticated technology today to make something that can help provide teaching aids in schools in need. In order to create a solution to the problems that occur above, the author introduces an application for lending mathematics teaching aids for elementary and junior high schools, which can later be used for solving these problems.

\section{RESEARCH METHODS}

\subsection{Data Collection Methods}

A study cannot be separated from the method used in the research because the method is one of the most important things in a study. According to Arikunto (2006: 160), the research method is a method that researchers usually use to collect research data.

This time, the research method used in scientific papers is the qualitative descriptive method by deepening the material through literature study. (Arikunto: 2006) explains that literature study in research collects data by searching for information through books, magazines, newspapers, and other literature that aims to form a theoretical basis. The data collection in scientific papers this time comes from books and journals where the data we use is secondary data.

\subsection{Data Analysis Methods}

\subsubsection{Data Collection Techniques}

The data used in this paper is secondary data from several sources, including research journals that are in accordance with the issues being discussed. The journals used as sources include the journal published by the State University of Jakarta for Mathematics and Natural Sciences, entitled "Development of Primary School Mathematics Learning Teaching Tools to Improve Students' Mathematical Thinking Ability" by Sudarwanto and Ibnu Hadi, a creative and innovative mathematics journal entitled: "Use of Teaching Aids to Improve Results Learning and Student Activeness on Opportunity Materials "by Masrukan. Behongang Scientific Journal with the title "Application for Borrowing Practical Tools in the Department of Computer and Communication Engineering Using Barcodes" by Eko Kusnadi, Alfrianus Papuas, and Arifin Tindi.

\subsubsection{Data Analysis Techniques}

This type of research is a literature study. (Arikunto: 2006) explains that literature study in research collects data by searching for information through books, magazines, newspapers, and other JMME page 1-13 
literature that aims to form a theoretical basis. Researchers carry out this literature study after determining the research topic and determining the formulation of the problem (Darmadi, 2011).

\subsubsection{Thinking Framework}

The frame of mind is made as shown in Figure 1 below.

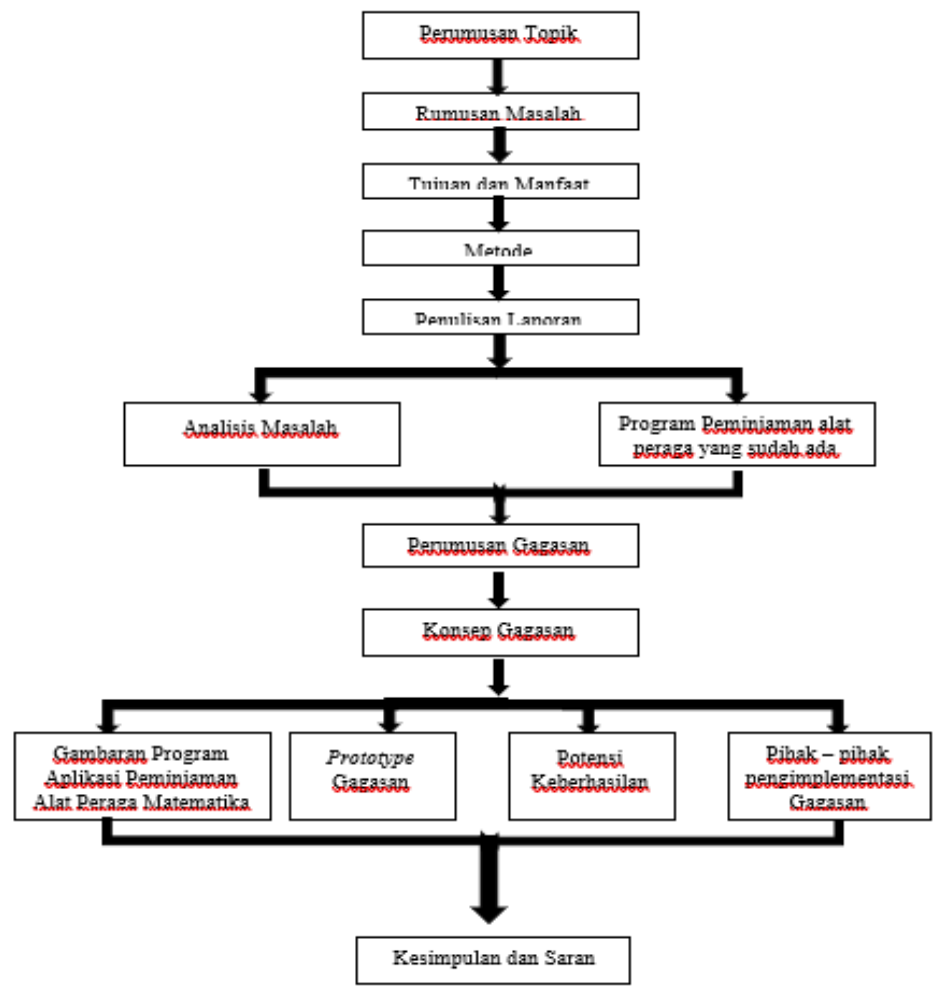

Figure 1. Graph of Thinking Framework Source: Author's Data Processing

\section{RESULTS AND DISCUSSION}

Several aspects can be developed in learning, especially mathematics. Among them, namely in understanding concepts, problem-solving and reasoning, and communication. Because the students in Primary and Junior High Schools view mathematics as a scary, confusing, and boring subject. We need to change the views/stereotypes of students in understanding mathematics. Mathematics itself is a basic science that for human life is very important and is the basis for the development of various other sciences. According to Erman, et al. In their statement, mathematics grows and develops for the development of other sciences as service providers. A student can understand something if the student understands and is able to explain something he understands.

It takes learning models that are in accordance with the objectives, type and nature of the material to be taught to increase students' understanding. The ability of students to understand a concept is low because the tedious process of learning mathematics tends to use a direct learning model that focuses only on the teacher. So that students find it difficult to express their ideas. Many math teachers 
are looking for other alternative methods to help teach exciting material and promote unique learning. In previous research on teaching practice by (Aleandra, et al., 2012) conducted a survey where the learning media used real tools or directly had teaching aids used by mathematics educators.

According to Joni (in Arjanggi, 2012), teaching aids are all forms of objects that are made and deliberately prepared as student learning media to understand or understand the material matter that the teacher is delivering. Teaching aids play an important role as a tool for teachers in the teaching and learning process itself to be more effective.

Based on research conducted by the Journal of Arjangga, in the previous 2012, it was found that in increasing student motivation and improving student learning outcomes itself required a teaching aid. At the first meeting there were $65 \%$ of students had not finished working on the quizzes and at the second meeting found that $92 \%$ of the students had completed the quiz. And from the results obtained an increase in the student learning process obtained from the percentage results in each meeting, of course, using real object media.

Based on the journal Polytechnic of North Nusa Tenggara, the application is a ready-to-use program that can be used to carry out commands from the user of the application, aiming to get a more accurate application. Application is a computer program or problem-solving using data processing techniques to run commands from users who aim to obtain more accurate results.

\subsection{Previous program}

Several other innovations are also applying practical lending tools in the department of computer and communication engineering using barcodes. It is explained that the use of barcodes itself makes it easier for laboratory personnel to take notes on borrowing laboratory equipment and is more efficient in terms of time and selecting equipment conditions for these systems using the Visual Basic programming language. NET, and the database itself uses MySQL. In terms of data storage itself, there are personal data from students and lecturers regarding the borrowing of practicum tools and data on practicum tools.

Previously, the National Library of Indonesia offered a digital library application or commonly known as iPusnas. iPusnas itself is a social media-based digital library application that can be downloaded in the play store or app store, which contains an eReader for reading e-books.

Previously, the borrowing of props was still done conventionally or manually and there were still many shortcomings, namely the data storage media still using paper, so it was vulnerable to loss if it had not been archived.

The school teaching aids lending program currently being run, some are still using the loan letter delivered to the intended school and some have started borrowing using a desktop-based props lending system as in the journal written by Faozi, Anosa Nur, published by BSI repository. 


\subsection{Overview}

Based on current conditions, there have been significant changes, including in the world of education. During a pandemic like today, schools or educational institutions are forced to move the teaching and learning process from being in classrooms to their homes, of course, limiting a student's activities. Furthermore, students will be more confused about finding the source of information from where, and the existing solution is by using the students' cellphones. By learning to find materials on search sites or other learning applications such as the Teacher Room, Quipper, Zenius, and others. Moreover, for the teachers themselves, they evaluate students' learning by visiting each student's house. Alternatively, some teachers are willing to teach their students privately or in groups of only 2-3 people, especially for teachers whose schools are in places where the network connection is not good. Furthermore, to make it easier for teachers to find learning media such as mathematics teaching aids, the author provides an alternative where current teachers can borrow teaching aids without making them themselves or having to come to school first. Apart from waiting for the Ministry of Education and Culture to publish various guidance materials such as TV programs, posters, books, and other supporting tools needed during face-to-face learning for green zone locations during the pandemic period. Moreover, to make it easier for teachers to find learning media such as mathematics teaching aids, the author provides an alternative where current teachers can borrow teaching aids without making them themselves or having to come to school first. Apart from waiting for the Ministry of Education and Culture to publish various guidance materials such as TV programs, posters, books, and other supporting tools needed during face-to-face learning for green zone locations during the pandemic period. Furthermore, to make it easier for teachers to find learning media such as mathematics teaching aids, the author provides an alternative where current teachers can borrow teaching aids without making them themselves or having to come to school first. Apart from waiting for the Ministry of Education and Culture to publish various guidance materials such as TV programs, posters, books, and other supporting tools needed during face-to-face learning for green zone locations during the pandemic period.

The general description of this elementary and junior high school mathematics teaching aid application, is where users can use an application downloaded on the play store or app store. In the application, users are initially asked to fill in their data and school addresses. Then, users can write down what props are needed so that later the address and name of the closest school will appear with the teaching aids needed by the user, and then they can immediately borrow the props needed by the user, and then they can immediately borrow the props. The intended school then approves this application, and then the following process is to choose a delivery service option that can help make it easier for users to get the loan props. 


\subsection{Schematic of Ideas}

Nowadays, technological developments are increasingly advanced and have penetrated into various aspects of human life, including education today. To make a student understand the concept, an effective method is also needed. Therefore, what needs to be considered in applying the method is the effectiveness in choosing a learning model. The ability of students to understand concepts is low because the mathematics learning process itself tends to use a learning model that is directly centered on the teacher. Of course, this can hinder the students' development in expressing themselves so that the solution to this problem can be found. One of the solutions we provide is ALGATIKA. ALGATIKA is a program that was initiated as a forum or as a solution to the availability of teaching aids.

\subsection{Prototype of ALGATIKA Program Application}

Seeing today's society who always carry an Android cell phone, of course, the writer can take advantage of this. Especially for education nowadays, where the author provides a loan application for teaching aids, schools far from the city center can borrow them by opening the application.

1. Initial display or logo of ALGATIKA: Mathematics Teaching Aids Loan Application

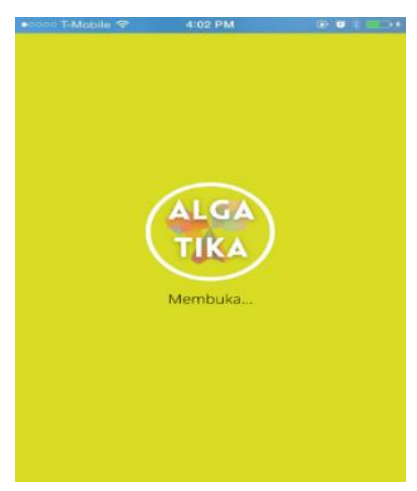

Figure 2. Logo

2. ALGATIKA program login display:

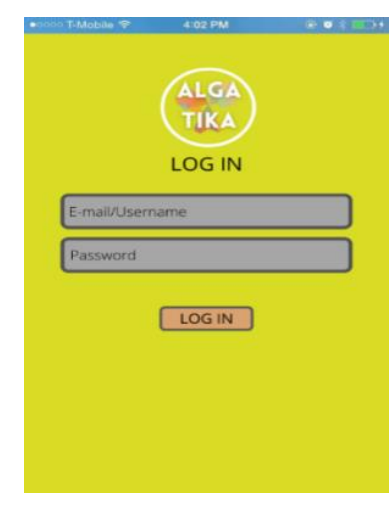

Figure 3. Login Display

For the initial appearance, visitors will be presented / displayed to log in first using an account that was previously registered by filling in the username and password. And if visitors have not registered themselves, they can register themselves in the "Sign Up" section. 
3. Display of account creation in the ALGATIKA program:

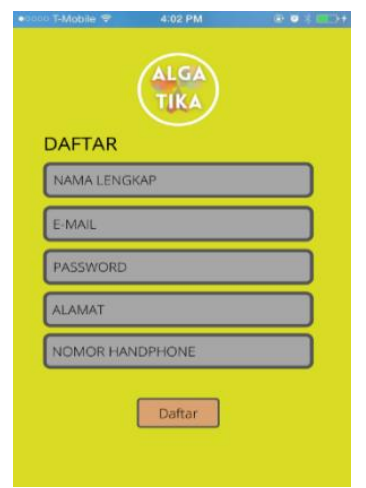

Figure 4. The register view

Visitors will be asked several personal data and school data questions, such as full name, e-mail address, and school origin. Furthermore, visitors will be created an account so that they can use the application.

4. Display a list of props available and being borrowed:

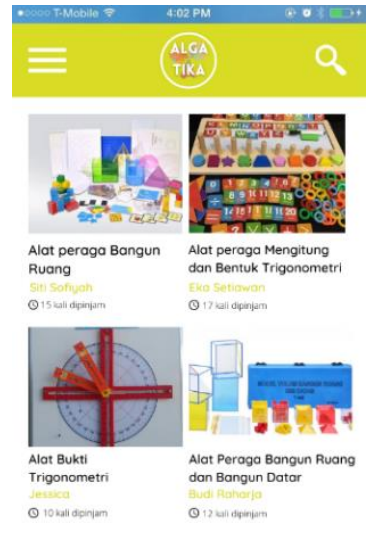

Figure 5. Tool List View

This section displays a list of props available on the spot and temporary props used or borrowed. If a visitor wants to borrow props that are temporarily borrowed, there will be a notification that the tool is temporarily borrowed, and visitors can borrow the tool after a specified period. To make it easier for visitors to find props at the top of the display list of props, there is a "search" feature to make it easier for visitors to find the needed tools.

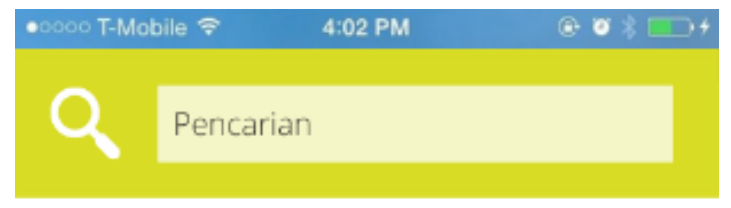

Figure 6. Tool Search View 
5. Display detailed information from schools that need:

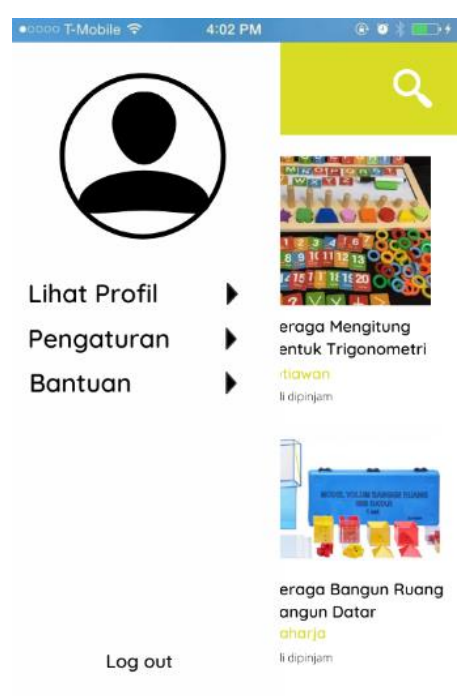

Figure 7. Home view

After searching for the props needed, information related to the props will be displayed, the length of time for the loan, etc. Moreover, those who already have an account, they can see their profile and social media applications.

\subsection{Potential Success of the ALGATIKA Program}

The following is the author describes three potentials that can be a driving factor for the realization of the ALGATIKA program:

1. Support from the Ministry of Education and Culture

The Ministry of Education encourages the growth and development of education in Indonesia, especially in 3T areas. Based on the national personality, the Ministry of Education and Culture and all elements of education and culture work together to advance education and culture in accordance with the vision and mission. The Ministry of Education and Culture is also committed to creating Pancasila Students. What is meant by Pancasila Students is to create Indonesian students as students who have a spirit of competence globally and have personalities that are in accordance with the values of Pancasila, with the main characteristics that must be possessed, namely mutual cooperation, reasoning critically, creatively and so on. The Ministry of Education and Culture provides encouragement to increase and equalize the quality of education services. And one of the conditions to be achieved is information and communication technology to support the improvement and distribution of the quality of education services. By developing mechanisms to encourage the provision of teacher competency development materials and quality and standardized media/teaching aids. Therefore, the author proposes that the platform-based mathematical teaching aid program will help teachers, especially those far from cities. The strategy drives this potential for success by the Ministry of Education and 
Culture, namely increasing student entrepreneurship and developing science and technology work-based business incubation centers/startups. By developing mechanisms to encourage teacher competency development materials and quality standardized media/teaching aids. Therefore, the author proposes that the platform-based mathematical teaching aid program will help teachers, especially those far from cities. The strategy drives this potential for success by the Ministry of Education and Culture, namely increasing student entrepreneurship and developing science and technology work-based business incubation centers/startups. By developing mechanisms to encourage teacher competency development materials and quality standardized media/teaching aids. Therefore, the author proposes that the platform-based mathematics teaching aid program will help teachers, especially those far from cities. This potential for success is driven by the strategy carried out by the Ministry of Education and Culture, namely increasing student entrepreneurship and developing science and technology work-based business incubation centers/startups.

2. Support from the City / Regency Education Office of Gorontalo Province

This education office provides support for educational information technology to support optimization in the teaching and learning process. The education office encourages students to be able to take advantage of this opportunity to be more independent and think critically in learning without having to rely on the material and tools provided by the teacher.

Therefore, through the ALGATIKA application as a provider of mathematics teaching aids that the author proposes, it will be beneficial for teachers and students, especially those far from cities and with pandemic conditions like this. The potential success of this application is also encouraged by the Gorontalo Province City / District Education Office in improving and realizing Indonesia's 2030 Sustainable Development Goals (SDGs).

3. Support for Subject Teachers' Deliberations (MGMP) for Primary and Junior High Schools throughout Gorontalo

The Subject Teacher Deliberation (MGMP) provides support with the ALGATIKA application so that teachers and students can know more about the material that requires teaching aids, and of course, it is easier and more efficient. Then able to arouse students' enthusiasm in mathematics lessons.

4. Provide Feedback for Teachers and Students

Learning media such as teaching aids can increase interest in mathematics lessons where previously students' views on mathematics subjects were difficult, scary, and others. And for teachers, they do not have to bother making their props and have to look for things in the city. Nowadays, by using cell phones owned by teachers and accessing applications, and being able to borrow them, time is more efficient. 


\subsection{ALGATIKA Program Effort}

The author will promote this ALGATIKA program to schools. By holding socialization online or offline, it strictly adheres to health protocols if it is carried out offline. Moreover, the author will take advantage of existing social media such as Instagram, Facebook, and others, to spread information or other notifications.

\subsection{Implementing Stakeholders of the ALGATIKA Program}

1. Ministry of Education and Culture.

2. City / Regency Education Office of Gorontalo Province.

3. Subject Teacher Deliberation (MGMP) for Primary and Junior High Schools throughout Gorontalo.

4. To Teachers in Gorontalo

\section{CONCLUSIONS AND SUGGESTIONS}

\subsection{Conclusion}

1. The ALGATIKA program provides solutions for teachers and students in the teaching and learning process. Provide a solution in the form of borrowing props that can be accessed through an application that can be downloaded from each cellphone.

2. This program works, or the scheme itself is like the applications installed on mobile phones in general. The difference is that because it is based on the world of education, the first login is required for the borrowing process. As is the case with lending books on the iPusnas application (national library in the form of a platform)

3. This program has outstanding potential for success to be realized, it can be seen from the existing supports, such as the support from the Ministry of Education and Culture, the Education Office in Gorontalo, and of course, this program has its advantages over the others in terms of

\subsection{Suggestions}

1. Increase in terms of cooperation between the roles of the Ministry of Education and Culture, the Gorontalo Province City / Regency Education office, MGMP, and other elements in realizing the programs offered by students, for example, in realizing the ALGATIKA program.

2. Intensive direct or offline socialization needs to be done when this pandemic period has ended, online socialization can also be held at this time so that teachers can find out what developments have occurred or what innovations are in the world of education today.

3. Applications are made by paying attention to several things, including having to be easily accessible and comfortable to use for users in the sense that the login process, until the goods arrive in the hands of the borrower, is not so confusing and requires someone who is an expert in application management such as conducting maintenance. 


\section{ACKNOWLEDGMENTS}

The author expresses his infinite thanks to all those who have assisted the author in completing this scientific paper as follows:

1. Resmawan, S.Pd., M.Si. as the Head of the Mathematics Study Program at the State University of Gorontalo

2. Nisky Imansyah Yahya, S.Pd., M.Si as the supervisor

3. And don't forget the support from various parties who have helped us gather information and more.

\section{REFERENCES}

Arjangga. (2012). Increasing Motivation and Student Learning Outcomes through the Application of Demonstration Methods assisted with Building Space Teaching aids in Mathematics Learning. Thesis, Vocational Faculty and Education Sciences. Tanjung Pura University.

Ministry of National Education. (2010). Guidelines for Learning Mathematics in Elementary Schools. Jakarta: Directorate of Kindergarten and Elementary Education

Faozi, and Nur, Anosa. (2020). Designing Desktop-Based Automotive Teaching Aids System at SMK Manggalatama Cilacap. BSI repository.

Figueira-Sampaio, A. da Silva, et al. (2012). Survey of Mathematics Practices with Concrete Materials used in Brazilian Schools. Procedia - Social and Behavioral Sciences, 93 (2013): 151-157. Retrieved March 1, 20211, from www. sciencedirect.com.

Wisdom, Nurul. (2016). Improved Mathematics Learning Outcomes Regarding Addition and Subtraction of Integers through the Tool of Number Ruler for Class IV Students of SDN 005 Samarinda Ulu. Pendas Mahakam Journal, 1 (1), 80-85.

Ministry of Education and Culture. (2020). "Guidelines for Organizing Learning in the Academic Year and New Academic Year in the Covid-19 Period", in www.kemdikbud.go.id, accessed March 2, 2021

Ministry of Education and Culture. (2020). "Strategic Plan of the Ministry of Education and Culture 2020-2024" in dikti.kemdikbud.go.id, accessed March 1, 2021.

Kusnadi, Eko, et al. (2019). Application for Borrowing Practicum Tools in the Department of Computer and Communication Engineering Using Barcodes. Behongang Scientific Journal, 1 (1), 1-6

Murdiyanto, Tri, Yudi Mahatma. (2014). Developing Mathematics Teaching Aids to Increase Primary School Students' Interest and Motivation in Learning Mathematics. Sarwahita Journal, 11 (1), $38-43$.

Nugraha, Depi Ardian, Somatanaya, AA. Gde. (2018). Training on Planning and Application of Elementary School Mathematics Teaching Aids. Siliwangi Service Journal, 4 (2), 186-191.

Phonapichat, Prathana SWSS, (2013). An analysis of elementary school students' difficulties in mathematical problem solving. Procedia - Social and Behavioral Sciences, Volume 116, pp. 31693174. Retrieved March 1, 20211, from www. sciencedirect.com.

Pranata, Ella. (2016). Implementation of Group Investigation (GI) Learning Model Assisted by Teaching Aids to Improve the Ability of Understanding Mathematical Concepts. Indonesian Journal of Mathematics Education, 1 (1), 34-38 
Rusmawati. (2017). The use of direct teaching aids in mathematics learning with simple fractions to improve student learning outcomes. Journal of Social Education, Science, and Humanities, 3 (2), 307-314.

Setyowati, Nining, Bambang Eko Susilo, Masrukan. (2016). The use of teaching aids to improve student learning outcomes and student activity on opportunity materials. Kreano's Journal, 7 (1), 24-30.

Sri Fajarwati, Munifah. (2010). Application of Reciprocal Teaching as an Effort to Improve the Understanding of Mathematical Concepts of Class XI Students of Accounting RSBI. Thesis Faculty of Mathematics and Natural Sciences, Yogyakarta State University.

Suwardi, Masni Erika Firmiana, Rohayati. (2014). The Effect of Using Teaching Aids on Mathematics Learning Outcomes in Early Childhood. AL-AZHAR INDONESIA Journal SERI HUMANIORA, 2 (4), 297-305. 